\title{
Health coaching strategies for weight loss: a systematic review and meta-analysis.
}

\author{
SIECZKOWSKA, S.M., PADILHA DE LIMA, A. SWINTON, P.A., DOLAN, E., \\ ROSCHEL, H. and GUALANO, B.
}

This is a pre-copyedited, author-produced version of an article accepted for publication in Advances in Nutrition following peer review. The version of record SIECZKOWSKA, S.M., PADILHA DE LIMA, A. SWINTON, P.A., DOLAN, E., ROSCHEL, H. and GUALANO, B. 2021. Health coaching strategies for weight loss: a systematic review and meta-analysis. Advances in nutrition [online], 12(4), pages 1449-1460, is available online at: https://doi.org/10.1093/advances/nmaa159

(c) The Author(s) 2020. Published by Oxford University Press on behalf of the American Society for Nutrition. This article is published and distributed under the terms of the Oxford University Press, Standard Journals Publication Model 


\section{Health coaching strategies for weight loss: a systematic review and meta-analysis}

Short title: Health coaching strategies for weight loss

Sofia Mendes Sieczkowska ${ }^{1}$, MSc, Alisson Padilha de Lima ${ }^{1,2}$, MSc, Paul Alan Swinton ${ }^{3}$, PhD, Eimear Dolan ${ }^{1}, \mathrm{PhD}$, Hamilton Roschel ${ }^{1}, \mathrm{PhD}$, Bruno Gualano ${ }^{1 *}, \mathrm{PhD}$.

${ }^{1}$ Applied Physiology \& Nutrition Research Group; School of Physical Education and Sport; Laboratory of Assessment and Conditioning in Rheumatology; School of Medicine, FMUSP, University of Sao Paulo, Sao Paulo, SP, BR

${ }^{2}$ School of Physical Education, Faculty IELUSC, Joinville-SC, BR

${ }^{3}$ School of Health Sciences, Robert Gordon University, Aberdeen, UK.

Corresponding author (to whom reprint requests should be addressed):

Bruno Gualano, $\mathrm{PhD}$

e-mail: gualano@usp.br

Trial Registration: PROSPERO (CRD42020159023)

Funding: FAPESP and CAPES.

Conflict of interest: The authors have nothing to disclose.

Data Share Statement: Data described in the manuscript, the code book, and analytic code will be made available upon reasonable request.

Word Count: 4240

Number of figures: 3

Number of tables: 2 


\section{List of abbreviations:}

95\% CrIs : Credible intervals

ES: Effect size (ES)

GRADE: Grading of Recommendations, Assessment, Development and Evaluation MCA: Multiple correspondence analysis

PICOS: Population, intervention, comparator, outcomes and study design

PRISMA: Preferred reporting items for Systematic Reviews and Meta-Analyses

PROSPERO: Prospective Register of Systematic Reviews

RCT: Randomized controlled trial

ROB: Risk of bias

VHL: Virtual Health Library 


\section{Abstract}

2 Health coaching has emerged as a potential supporting tool for health professionals to

3

4 We conducted a systematic review and meta-analysis to synthesize and evaluate the

5 quality of evidence supporting the use of self-reported health coaching for weight loss.

6 Seven electronic databases (PubMed, Web of Science, Scopus, Cochrane, Psyinfo, VHL,

7 and Scielo) were independently searched from inception to May 2020. This review was

conducted in accordance with PRISMA guidelines and quality of evidence was assessed using GRADE recommendations. Any study that investigated a self-reported health coaching intervention with the goal of inducing weight loss in individuals of any age, health or training status was considered for inclusion. Quantitative data were analysed using multi-level hierarchical meta-regression models conducted within a Bayesian framework. Six hundred and fifty-three studies were screened and 38 were selected for inclusion. The quality of evidence supporting outcomes based on the entire evidence base was very low and studies were deemed to have high risk of bias. Meta-analysis of controlled studies provided evidence of an effect favouring coaching compared to usual care, but was trivial in magnitude $\left(\mathrm{ES}_{0.5}:-0.09 ; 95 \% \mathrm{CrI}:-0.17,-0.02\right)$. The multilevel extension of Egger's regression-intercept test indicated the existence of publication bias, while a sensitivity analysis based only on those studies deemed to be of high-quality provided no evidence of an effect of coaching on weight loss $\left(\mathrm{ES}_{0.5}:-0.04 ; 95 \% \mathrm{CrI}\right.$ : $0.12,0.09)$. Considered collectively, the results of this investigation indicate that the available evidence is not of sufficient quality to support the use of self-reported health coaching as a health care intervention for weight loss.

Key-words: behaviour change, weight-loss, health coaching, weight, BMI, waist circumference. 


\section{Introduction}

The quest for effective treatment and management strategies is an everlasting issue in obesity and overweight care. Despite the plethora of studies supporting lifestyle changes (i.e., physical activity and dietary habits) for excessive weight management $(1,2)$, longterm sustainability of behaviour changes are problematic (3), and often result in significant weight regain and health impairment $(4,5)$. Counselling approaches and integrative theories of behavioural change, such as motivational interviewing and the transtheoretical model, are often used to facilitate longer term lifestyle changes and are well-supported by the available evidence base (6-8). More recently, health coaching has also emerged as a supporting tool for health professionals to overcome behavioural barriers (9-11). Whilst no consensual definition exists, health coaching is considered to be a goal-oriented, client-centred partnership focused on health and based on a process of enlightenment and empowerment of the client $(12,13)$. The use of health coaching is widespread and appears to be ever-increasing. Indeed, a study commissioned by the International Coaching Federation in 2016 reported that the total number of professional coach practitioners worldwide is approximately 53,300, with most of these located in higher-income regions, and that the U.S. estimated market value for personal coaching was $\$ 1.02$ billion (14).

The term health coaching is often used to describe activities usually associated with other health care practitioners, including nutritionists, fitness trainers, behavioural counsellors, and/or behavioural therapists, all of whom are trained in the delivery of well-established, evidence-based interventions that are known to promote health related benefits, including weight loss $(8,15,16)$. However, despite the rapid expansion of a health coaching industry in recent years, there has been no synthesis of the scientific evidence to determine exactly how coaches are implementing their interventions in practice, nor whether there is 
52 scientific support for its use either as an adjunct or a main therapy in weight management.

53 In this scenario, it is important to identify what has actually been done under the rubric 54 of "health coaching" and whether this has been effective. As an intervention model that 55 intends to hold its own episteme (e.g., theoretical background, implementation 56 techniques, clinical tools and approaches, professional training and certification 57 programs), health coaching should be subject to the same level of scientific scrutiny as 58 all other health care interventions. Accordingly, the aim of the current investigation was to synthesize and evaluate the quality of evidence supporting the use of self-reported health coaching for weight loss.

61

62 Methods

63 Quality of evidence was determined using the Grading of Recommendations, Assessment, Development and Evaluation (GRADE) approach. The evidence base for assessment of these domains was selected during a systematic literature search, the protocol for which was designed in accordance with PRISMA guidelines. This systematic

67 review was registered in the International Prospective Register of Systematic Reviews 68 (PROSPERO - CRD42020159023). The inclusion and exclusion criteria were assigned according to the population, intervention, comparator, outcomes and study design (PICOS). To better capture the features and outcomes of this intervention in its miscellanea, we reviewed all studies that were self-defined as health coaching.

$73 \quad$ Eligibility criteria

- Population: Individuals of any age, health, or training status, who had a goal of weight loss. 
- Intervention: Health coaching, lifestyle coaching or any type of coaching with the goal of inducing weight loss. Given the lack of a consensual definition of health coaching, and to better capture all the possible ways this intervention has been employed in literature, we included any study described as "coaching" by the authors. No restrictions on intervention duration was placed.

- Comparator: Both controlled and uncontrolled interventions were considered for inclusion, with comparators comprising usual care.

- Outcomes: Body mass $(\mathrm{kg})$, body mass index $\left(\mathrm{kg} \cdot \mathrm{m}^{-2}\right)$ and/or waist circumference $(\mathrm{cm})$.

- Study Design: Any study design that comprised a coaching intervention for weight loss with relevant outcomes assessed pre and post intervention was considered for inclusion.

\section{Search Strategy, Study Selection and Data Extraction}

Seven electronic databases (PubMed, Web of Science, Scopus, Cochrane, Psyinfo, VHL, and Scielo) were independently searched by two members of the review team, with no restrictions placed on date or language. The search terms and descriptors used were related to health coaching ("motivational interviewing based health coaching" OR "lifestyle coaching" OR "health coaching" OR "dietary coaching" OR "nutrition coaching" OR "weight loss coaching" OR "physical coaching" OR "coaching intervention") and study design ("randomized clinical trial" OR "randomized controlled trial" OR "nonrandomized controlled trial" OR "clinical trial" OR "before-after trial" OR "crossover Trial"). The searches were conducted in June of 2020, using the search strategy presented in the supplemental file 1. All articles identified in the search strategy were screened using a 2-stage strategy, namely 1) Title and abstract screen and 2) Full text 
101

102

103

104

105

106

107

108

109

110

111

112

113

114

115

116

117

118

119

review and any discrepancies were resolved through discussion, or third-party mediation, if required. To identify other relevant study data, we also screened reference lists of primary studies included and review articles. Data were extracted using a pre-piloted spreadsheet and independently verified by a second member of the review team. Study authors were contacted to request additional or missing data if required; the authors were given one month to respond. If the authors of the studies with missing outcome data did not respond, the articles were not considered further.

\section{Assessment of evidence quality}

The primary outcome of this review was the quality of the evidence base as a whole. This was supported by the results from three statistical analysis models. The first of these estimated the influence of coaching on weight loss using controlled intervention trials only. Two secondary analyses were also conducted, namely the influence of coaching on weight loss using all trials that included a pre-post measure (controlled and uncontrolled) and a sensitivity analysis based only on those studies deemed to be of high quality. The quality of each of these outcomes was ascertained using a strategy based on the recommendations of the Grading of Recommendations Assessment Development and Evaluation (GRADE) working group (17) in accordance with 8 separate domains. Potential downgrading factors included risk of bias, indirectness, inconsistency, imprecision or the presence of publication bias, while potential upgrading factors included the presence of large-effects, evidence of dose-response and the presence of plausible residual confounding factors. Starting quality level was ranked as high for randomized controlled trials, moderate for nonrandomized controlled trials, and low for uncontrolled trials. Risk of bias (ROB) was independently appraised for each individual study by 2 reviewers, using the Cochrane Collaboration Risk of Bias tool (18). The tool 
126 evaluated studies according to 7 domains, namely random sequence generation;

127 allocation concealment; participant blinding; evaluator blinding; incomplete outcomes;

128 selective reporting and other biases, which we defined as the lack of use of intention to treat analyses and appropriateness of the statistical analyses undertaken. Studies were assigned either 0 (low ROB); 1 (unclear ROB) or 2 (high ROB) points for each of these domains, and the overall risk of bias was based on the cumulative points awarded to each individual study outcome and within the following categories: low $\mathrm{ROB}<4$; moderate ROB 5-9; and high ROB 10-16. The quality rating for studies deemed to have a moderate ROB were downgraded one level, while studies with a high ROB were downgraded by two levels. Indirectness of evidence was ascertained based on 4 questions that we considered key to the quality of these particular studies, namely 1) Was the intervention delivered by health professionals (e.g., nurses, psychologists, dietitians, health counsellors, exercise trainers, or graduate students in any health area)? 2) Were the health coaches specifically trained in the delivery of this intervention? 3) Was the intervention described in sufficient detail to allow replication? And 4) In addition to weight loss, did the authors report changes in target behaviour (e.g., modifications in diet or physical activity levels)? Studies were downgraded a quality level if the answer to any of these questions was no, and were downgraded 2 quality levels if 2 or more questions were answered no. Both ROB and directness were initially assessed at the level of the individual study, and the median ratings were used to describe the evidence base as a whole, whereas the median ratings for each study included in each individual statistical analysis were used to describe the quality of that outcome. Inconsistency was ascertained using the meta-analysis results, and was based on visual inspection of effect size estimates, whether or not confidence intervals overlapped, and on statistical tests for heterogeneity (described below in the data analysis section). Imprecision was judged 
151 based on the number of outcomes available (with any analysis for which $<3$ independent

152 outcomes were available downgraded) and on visual analysis of the width of the confidence intervals. Publication bias was assessed using Egger's regression-intercept test (described below in the data analysis section) along with visual inspection of funnel plots.

\section{Data Analysis}

Data were extracted from studies comprising both between- and within-group designs. Pairwise effect sizes were calculated by dividing mean differences by pooled standard deviations. At the study level, variance of effect sizes were calculated according to standard distributional assumptions (19). All meta-analyses were conducted within a Bayesian framework enabling interpretation with subjective probabilities. Three-level hierarchical models were conducted to account for covariance between multiple outcomes presented in the same study, as described elsewhere (20). Inferences from all analyses were performed on posterior samples generated using Hamiltonian Markov Chain Monte Carlo method and through the use of Bayesian 95\% credible intervals (CrIs) constructed to enable probabilistic interpretations of parameter values. Interpretations were based on visual inspection of the posterior sample, the median value $\left(\mathrm{ES}_{0.5}: 0.5\right.$ - quantile) and 95\%CrIs. Cohen's standard threshold values (21) of $0.2,0.5$, and 0.8 were used to describe effect sizes as small, moderate and large, with values between 0 and 0.2 described as trivial. Analyses were performed using the R wrapper package brms, which interfaced with Stan to perform sampling (22). Convergence of parameter estimates was obtained for all models with Gelman-Rubin R-hat values below 1.1 (23). Assessment of publication bias was made using a multilevel extension of Egger's regression-intercept test with effect sizes regressed on the inverse of standard errors (24). To describe 
underlying structure in research quality, multiple correspondence analysis (MCA) was conducted. The MCA results were used to identify percentage contribution to the dimensions constructed. MCA analysis was completed using the FactoMineR package (25).

\section{Results:}

\section{Description of included studies}

The search strategy resulted in 1291 manuscripts, and 38 of these were selected for inclusion in the review (see Figure 1 for search flow diagram). In relation to study design, the included studies comprised 21 randomized controlled trials, 5 randomized noncontrolled trials, 4 non-randomized controlled trials, 7 single-group trials and 1 case study. The included studies comprised 10717 individuals: 34 studies with males and females, 2 studies with males only (26,27), 1 study with females only (28), and 1 study which did not specify (29). Two studies were conducted with individuals aged $<18$ years $(30,31)$ and all others studies were conducted with individuals aged $18-65$ years. Thirtyfive of the 38 included studies investigated populations with obesity and/or cardiometabolic conditions, one investigated patients with chronic kidney disease, while the remaining two studies investigated patients with cancer (32). Twenty-one studies had a primary goal of inducing weight loss, while this was considered a secondary outcome in the remaining 17 studies. The frequency (twice weekly - once per month) and duration $(6-72$ weeks $)$ of the interventions varied widely. Details of the coaching interventions are summarized in Table $\mathbf{1 .}$

(1) 
201

202

203

204

205

206

207

208

209

210

211

212

213

214

215

216

217

218

219

220

221

222

223

224

225

\section{Analysis of evidence quality}

Analysis of quality based on the entire evidence base $(n=38)$ was ascertained at the individual study level, and according to study design, risk of bias and indirectness. This assessment indicated that $57.9 \%$ of the studies were of very low quality, $13.1 \%$ low quality, $7.9 \%$ moderate quality and $21.0 \%$ high quality.

\section{Meta-analysis}

Of the 38 studies included in the review, 12 studies had insufficient data to warrant inclusion in the meta-analysis (e.g., data were reported as \% change only or without an estimate of variation). The primary meta-analysis was completed on 16 controlled studies comprising 47 outcomes from a total of 2501 participants (overall $n=156$; range: 10 to 763) allocated to coaching interventions and a total of 1729 participants (overall $n=108$; range: 10 to 360 ) allocated to usual care. The analyses indicated a trivial effect favouring coaching compared to usual care $\left(\mathrm{ES}_{0.5}:-0.09 ; 95 \% \mathrm{CrI}:-0.17,-0.02 ; \tau_{0.5}: 0.11 ; 95 \% \mathrm{CrI}\right.$ : $0.05-0.21$; ICC: $0.04 ; 95 \% \mathrm{CrI}: 0.00,0.45$; Figure 2 ). However, the probability that the pooled effect in favour of coaching could be classified as small or beyond was very low ( $d \leq-0.2$; P-value: 0.007$)$ and classified as medium or beyond was effectually zero ( $d \leq-$ 0.5; P-value: <0.0001). The multilevel extension of Egger's regression-intercept test indicated the existence of asymmetry and publication bias with potential missing small sample studies reporting effects sizes less favourable to coaching (Eggers 0.5 : -0.12 ; $95 \% \mathrm{CrI}:-0.24,0.00)$. Additionally, the analysis identified that studies categorized as very low quality tended to generate larger effect sizes favouring coaching $\left(\mathrm{ES}_{0.5}\right.$ : -0.14 ; $95 \% \mathrm{CrI}:-0.32,-0.01)$. The quality of evidence supporting this outcome was very low (see

Table 2). To investigate associations between intervention duration and pooled effect size, studies were split into short-term ( $\leq 12$ weeks, 16 outcomes) and long-term $(>12$ 
weeks, 31 outcomes). Results demonstrated similar pooled effect sizes across durations with the median effect size difference between short- and long-term equal to $\mathrm{ES}_{0.5}: 0.002$; 95\%CrI: $-0.14,0.16$. A sensitivity analysis based on studies whereby weight loss was described as the primary outcome showed similar results and did not meaningfully alter data interpretation (data not shown).

A secondary analyses was conducted using pre-post data from all coaching interventions (controlled and uncontrolled). This analysis was based on 26 studies comprising 77 outcomes from a total of 3601 participants (overall $n$ : 139; range: $9-763$ ). The results also indicated a trivial effect similar to that identified using control group data favouring coaching $\left(\mathrm{ES}_{0.5}:-0.10 ; 95 \% \mathrm{CrI}:-0.15,-0.05 ; \tau_{0.5}: 0.07 ; 95 \% \mathrm{CrI}: 0.04,0.13\right.$; ICC: 0.09 ; 95\%CrI: 0.00, 0.34; Figure 3). The quality of evidence supporting this outcome was very low (Table 2) and the probability that the pooled effect in favour of coaching could be classified as small or beyond was effectively zero $(\mathrm{d} \leq-0.2$; P-value: $<0.0001)$.

A final sensitivity analysis was completed with what was considered the most reliable data which was from RCT's judged as high-quality, which was based on study design, risk of bias and indirectness. This criterion was met by 5 studies and comprised 20 outcomes from a total of 554 participants (overall $n=111$; range: 12 to 189 ) allocated to coaching interventions and a total of 506 participants (average $n=101$; range: 26 to 191) allocated to usual care. The pooled effect size demonstrated minimal evidence of any effect $\left(\mathrm{ES}_{0.5}:-0.04 ; 95 \% \mathrm{CrI}:-0.12,0.09 ; \tau_{0.5}: 0.04 ; 95 \% \mathrm{CrI}: 0.00,0.20 ;\right.$ ICC: 0.22 ; 95\%CrI: 0.00, 0.70).

\section{Discussion}

The purpose of this investigation was to evaluate the quality of evidence supporting the use of self-reported health coaching for weight loss. Considered collectively, the available 
studies had a high risk of bias, and evidence of publication bias favouring positive results was observed. Information regarding the professional status and level of administrator training was scant, as were specific details regarding the coaching intervention itself. From the meta-analyses, we identified a trivial effect from controlled studies favouring the use of coaching for weight loss, but the quality of evidence supporting this finding was very low. Lower quality studies were more likely to report results that favoured the use of coaching over usual care, whereas studies deemed to be of high-quality showed no effect of health coaching on weight loss. Based on this objective assessment of study parameters, combined with meta-analysis results, we conclude that the current evidence base is not of sufficient quality to support the use of self-reported coaching as a health care intervention for weight loss.

Transparency in reporting is widely recognised as an important factor determining the quality of studies, as it allows for a more complete evaluation of methodological appropriateness and the possibility for adequate replication (33). Published guidelines are available that clearly define the parameters that should be described when reporting health related research $(34,35)$. including specific guidelines for psychological interventions (36). The present systematic review indicates that these guidelines were not adequately adhered to with most of the included studies deemed to be of high risk of bias, while the overall quality of evidence supporting effects reported was largely of low and very lowquality $(\sim 70 \%)$. Of particular concern was the lack of information on the professional status and training level of those administering the health coaching intervention, along with scant information on whether the intervention had an appreciable effect on the intended behaviours. Without such information it remains difficult to evaluate the appropriateness of health coaching, or indeed, what exactly it comprises. 
275 An important limitation of the body of evidence is the lack of a consensual definition of 276 health coaching and how the practice differs from other lifestyle or behaviour change

277 interventions. In the absence of a clearly-defined explanation of what distinguishes health coaching from other models, we chose to select studies that were self-reported as health 279 coaching by their own authors. This approach allowed us to evaluate the actual 280 interventional features of self-reported health coaching in its miscellany. To advance this research area and to develop the evidence base required to indicate whether or not the widespread public practice and implementation of health coaching interventions is warranted, we recommend that a clear definition of health coaching is developed, along with recommendations of the precise parameters that define what constitutes this intervention.

Most of the studies evaluated in this review described their intervention as being based on one $(27,30,37-55)$, or a combination of two or more $(26,31,32,56-61)$ counselling approaches and theories of behavioural change, with motivational interviewing and the transtheoretical model most frequently cited. Both of these theoretical models follow clearly defined procedures $(62,63)$ and are supported by extensive evidence bases $(6-8)$. Despite stating that interventions were underpinned by theory, the majority of studies did not clearly establish how theory was implemented, or indeed, provide justification for such implementation and interpretation. One thing that is clear is that the adaptations made do not appear to be fit for purpose. For example, a large body of research indicates a favourable effect of motivational interviewing on weight loss $(7,16,64,65)$, with metaanalytic results showing standardized effects to the order of approximately $0.5-0.7$

297 (16,64). In contrast, the current meta-analysis of all controlled studies estimated only a trivial effect of health coaching over usual care, with $\mathrm{ES}_{0.5}:-0.09 ; 95 \% \mathrm{CrI}:-0.17,-0.02$ 
coaching. In a previous review evaluating the effectiveness of motivational interviewing, most studies reported specific training (13 of 15) and engagement metrics (11 of 15) (65). Conversely, in our review, several studies (17 of 38) did not even report whether health coaching was able to modify behaviour, hampering firm conclusions of a cause-and-effect relationship between potential lifestyle changes (e.g., diet and physical activity) and the outcome (weight loss). Therefore, the discrepant results reported for the efficacy of health coaching and other evidence-based health care interventions are not surprising, since these interventions fundamentally differ as regard to (at least) their scientific implementation and appraisal. Therefore, while health coaching programs may have incorporated a few practical and theoretical elements from other well-accepted counselling approaches and theories (e.g., motivational interviewing or the transtheoretical model), it remains unclear $i$ ) how this reconciles as a reproducible, coherent intervention in the clinical setting, and, more importantly, ii) to what extent this intervention can benefit patients. In order to eventually benefit from health coaching, much more insights into essential elements of this intervention is needed.

At least for weight loss, it seems unlikely that such trivial effects found in the current study would have any clinically relevant health benefits. It is also important to highlight that the trustworthiness of these estimates is very low, as observed in our quality assessment. Indeed, when considering only those trials judged as high-quality $(n=5)$, minimal evidence of an effect of health coaching was observed (ES $0.5:-0.04 ; 95 \% \mathrm{CrI}$ : $0.12,0.09)$. The effects favouring health coaching found in higher quality studies were even lower than those of poorer quality studies, evidencing a publication bias and further undermining the confidence in the efficacy of this intervention.

This study has limitations. First, given the lack of a consensual definition of what coaching is, we decided to review all studies self-reported as health coaching. Although 
325 this approach enabled us to thoroughly describe what has been done under the "rubric" 326 of coaching (Table 1), it is possible that this review missed some studies that tested other

327 similar interventions, but that were not identified as such by the authors. Second, health coaching may be potentially used in several health related contexts (e.g., wellness, disease

329 prevention and management). Thus, the current conclusions should be restricted to the 330 context of weight loss, which is one of the main goals of health coaching in clinical practice.

332 Based on this objective assessment of study parameters, combined with meta-analysis results, we conclude that the current evidence base is not of sufficient quality to support

334 the use of self-reported coaching as a health care intervention for weight loss. Despite its 335 wide-spread use, the practice of health coaching appears to lack its own episteme, and the available scientific use does not support the use of self-reported health coaching strategies 337 for weight loss. We recommend that pending more precise definitions of what exactly health coaching constitutes, and the publication of higher quality research supporting its use, self-reported health coaching strategies should be regulated to ensure evidence-based and fit for purpose practice. As a research agenda, researchers should focus on $i$ ) reaching consensus on what health coaching is and what is its guiding concepts; ii) better defining and describing their coaching interventions; iii) properly training health professionals to deliver coaching interventions consistently; and $i v$ ) conducting pragmatic, randomized controlled trials following CONSORT guidelines to test clinically significant outcomes. 
347 BG designed the study. SMS, APL and ED conducted the systematic review. PAS did the meta-analysis. SMS, ED and HR wrote the first draft of the report. BG and HR revised the manuscript. All authors read and approved the final version.

\section{Acknowledgments}

Sofia Mendes Sieczkowska, Bruno Gualano and Eimear Dolan are supported by grants from the Fundação de Amparo à Pesquisa do Estado de São Paulo (FAPESP;2019/15231$88887.473556 / 2020-00)$.

\section{References}

1. Kushner RF. Weight Loss Strategies for Treatment of Obesity: Lifestyle Management and Pharmacotherapy. Prog Cardiovasc Dis [Internet]. Elsevier Inc.; 2018;61:246-52. Available from: https://doi.org/10.1016/j.pcad.2018.06.001

2. Ashton LM, Sharkey T, Whatnall MC, Haslam RL, Bezzina A, Aguiar EJ, Collins CE, Hutchesson MJ. Which behaviour change techniques within interventions to prevent weight gain and/or initiate weight loss improve adiposity outcomes in young adults? A systematic review and meta-analysis of randomized controlled trials. Obes Rev. 2020;1-19.

3. Bouton ME. Why behavior change is dif fi cult to sustain th. 2014;68:29-36.

4. Baak MA, Mariman ECM. Mechanisms of weight regain after weight loss - the 
role of adipose tissue. Nat Rev Endocrinol [Internet]. Springer US; 2019;15. Available from: http://dx.doi.org/10.1038/s41574-018-0148-4

5. Sainsbury K, Evans EH, Pedersen S, Marques MM, Teixeira PJ, Lähteenmäki L, Stubbs RJ, Heitmann BL, Sniehotta FF. Attribution of weight regain to emotional reasons amongst European adults with overweight and obesity who regained weight following a weight loss attempt. Eat Weight Disord - Stud Anorexia, Bulim Obes [Internet]. Springer International Publishing; 2019;24:351-61. Available from: http://dx.doi.org/10.1007/s40519-018-0487-0

6. Vanbuskirk KA, Wetherell JL. Motivational interviewing with primary care populations: A systematic review and meta-analysis. Journal of Behavioral Medicine. 2014.

7. Ekong G, Kavookjian J. Motivational interviewing and outcomes in adults with type 2 diabetes: A systematic review. Patient Education and Counseling. 2016.

8. Mastellos N, Gunn LH, Felix LM, Car J, Majeed A. Transtheoretical model stages of change for dietary and physical exercise modification in weight loss management for overweight and obese adults. Cochrane Database of Systematic Reviews. 2014.

9. Butterworth SW, Linden A, McClay W. Health coaching as an intervention in health management programs. Dis Manag Heal Outcomes. 2007;15:299-307.

10. Kreitzer MJ, Sierpina VS, Lawson K. Health Coaching: Innovative Education and Clinical Programs Emerging. Explor J Sci Heal. 2008;4:154-5.

11. Finn HE, Watson RA. The Use of Health Coaching to Improve Health Outcomes: Implications for Applied Behavior Analysis. Psychol Rec. The Psychological Record; 2017;67:181-7.

12. Olsen JM. Health Coaching: A Concept Analysis. Nurs Forum. 2014;49:18-29. 
13. Wolever RQ, Eisenberg DM. What Is Health Coaching Anyway? BMC Health Serv Res. 2011;171:2017-8.

14. LaRosa J. U.S. Personal Coaching Industry Tops \$1 Billion, and Growing [Internet]. 2018 [cited 2020 Apr 23]. Available from:

https://blog.marketresearch.com/us-personal-coaching-industry-tops-1-billionand-growing

15. Coleman MT, Pasternak RH. Effective Strategies for Behavior Change. 2012;39:281-305.

16. Armstrong MJ, Mottershead TA, Ronksley PE, Sigal RJ, Campbell TS, Hemmelgarn BR. Motivational interviewing to improve weight loss in overweight and/or obese patients: A systematic review and meta-analysis of randomized controlled trials. Obes Rev. 2011;

17. Guyatt G, Oxman AD, Akl EA, Kunz R, Vist G, Brozek J, Norris S, Falck-Ytter Y, Glasziou P, Debeer H, et al. GRADE guidelines: 1. Introduction - GRADE evidence profiles and summary of findings tables. J Clin Epidemiol. 2011;64:383-94.

18. Higgins JPT, Altman DG, Gotzsche PC, Juni P, Moher D, Oxman AD, Savovic J, Schulz KF, Weeks L, Sterne JAC, et al. The Cochrane Collaboration's tool for assessing risk of bias in randomised trials. Bmj [Internet]. 2011;343:d5928. Available from: http://dx.doi.org/10.1136/bmj.d5928

19. Morris SB. Estimating effect sizes from pretest-posttest-control group designs. Organ Res Methods. 2008;

20. Dolan E, Swinton PA, Painelli VDS, Hemingway BS, Mazzolani B, Smaira FI, Saunders B, Artioli GG, Gualano B. A Systematic Risk Assessment and MetaAnalysis on the Use of Oral $\beta$-Alanine Supplementation. Advances in Nutrition. 
2019.

21. Cohen J. Statistical Power Analysis for the Behavioural Science (2nd Edition). Statistical Power Anaylsis for the Behavioral Sciences. 1988.

22. Bürkner PC. brms: An R package for Bayesian multilevel models using Stan. J Stat Softw. 2017;

23. Gelman A, Carlin JB, Stern HS, Dunson DB, Vehtari A, Rubin DB. Bayesian data analysis, third edition. Bayesian Data Analysis, Third Edition. 2013.

24. Fernández-Castilla B, Declercq L, Jamshidi L, Beretvas SN, Onghena P, Van den Noortgate W. Detecting Selection Bias in Meta-Analyses with Multiple Outcomes: A Simulation Study. J Exp Educ. 2019;

25. Husson F, Josse J, Le S, Mazet J. FactoMineR: Multivariate Exploratory Data Analysis and Data Mining. R package version 1.31.4. 2015. 2015.

26. Lancha AH, Sforzo GA, Pereira-Lancha LO. Improving Nutritional Habits With No Diet Prescription: Details of a Nutritional Coaching Process. Am J Lifestyle Med. 2018;12:160-5.

27. Viglione C, Bouwman D, Rahman N, Fang Y, Beasley JM, Sherman S, PiSunyer X, Wylie-Rosett J, Tenner C, Jay M. A technology-assisted health coaching intervention vs. enhanced usual care for Primary Care-Based Obesity Treatment: A randomized controlled trial. BMC Obes. BMC Obesity; 2019;6:111.

28. Rimmer JH, Rauworth A, Wang E, Heckerling PS, Gerber BS. A randomized controlled trial to increase physical activity and reduce obesity in a predominantly African American group of women with mobility disabilities and severe obesity. Prev Med (Baltim) [Internet]. The Institute For Cancer Prevention; 2009;48:473-9. Available from: 
http://dx.doi.org/10.1016/j.ypmed.2009.02.008

29. Johnson KE, Alencar MK, Coakley KE, Swift DL, Cole NH, Mermier CM, Kravitz L, Amorim FT, Gibson AL. Telemedicine-Based Health Coaching Is Effective for Inducing Weight Loss and Improving Metabolic Markers. Telemed e-Health. 2019;25:85-92.

30. Taveras EM, Marshall R, Sharifi M, Avalon E, Fiechtner L, Horan C, Gerber MW, Orav EJ, Price SN, Sequist T, et al. Comparative Effectiveness of ClinicalCommunity Childhood Obesity Interventions. JAMA Pediatr [Internet]. 2017;171:e171325. Available from: https://www.faa.gov/data_research/aviation/aerospace_forecasts/media/FY201737_FAA_Aerospace_Forecast.pdf

31. Ball GDC, Mackenzie-Rife KA, Newton MS, Alloway CA, Slack JM, Plotnikoff RC, Goran MI. One-on-one lifestyle coaching for managing adolescent obesity: Findings from a pilot, randomized controlled trial in a real-world, clinical setting. Paediatr Child Health (Oxford). 2011;16:345-50.

32. Hawkes AL, Patrao TA, Green A, Aitken JF. CanPrevent: A telephone-delivered intervention to reduce multiple behavioural risk factors for colorectal cancer. BMC Cancer [Internet]. BMC Cancer; 2012;12:1. Available from: BMC Cancer

33. Moher D, Simera I, Schulz KF, Hoey J, Altman DG. Helping editors, peer reviewers and authors improve the clarity, completeness and transparency of reporting health research. 2008;3:11-3.

34. EQUATOR (Enhancing the quality and transparency of health research) network. Japanese Pharmacology and Therapeutics. 2016.

35. Groves T. Enhancing the quality and transparency of health research. BMJ. 2008.

36. Hales AH, Wesselmann ED, Hilgard J. Improving Psychological Science through 
Transparency and Openness : An Overview. Perspectives on Behavior Science; $2019 ; 13-31$.

37. Chapman A, Browning CJ, Enticott JC, Yang H, Liu S, Zhang T, Thomas SA. Effect of a health coach intervention for the management of individuals with type 2 diabetes mellitus in China: A pragmatic cluster randomized controlled trial. Front Public Heal. 2018;6:1-14.

38. Bus K, Peyer KL, Bai Y, Ellingson LD, Welk GJ. Comparison of In-Person and Online Motivational Interviewing-Based Health Coaching. Health Promot Pract [Internet]. 2018;19:513-21. Available from: https://doi.org/10.1177/1524839917746634

39. Miller KE, Martz DC, Stoner C, Jowers A, Taheri ML, Sarzynski MA, Davis RAH, Plaisance EP. Efficacy of a telephone-based medical nutrition program on blood lipid and lipoprotein metabolism: Results of Our Healthy Heart. Nutr Diet. $2018 ; 75: 73-8$.

40. Williams A, Wiggers J, O’Brien KM, Wolfenden L, Yoong SL, Hodder RK, Lee H, Robson EK, McAuley JH, Haskins R, et al. Effectiveness of a healthy lifestyle intervention for chronic low back pain: A randomised controlled trial. Pain. 2018;159:1137-46.

41. Bollyky JB, Bravata D, Yang J, Williamson M, Schneider J. Remote Lifestyle Coaching Plus a Connected Glucose Meter with Certified Diabetes Educator Support Improves Glucose and Weight Loss for People with Type 2 Diabetes. J Diabetes Res. 2018;2018:3961730.

42. Chad-Friedman E, Pearsall M, Miller KM, Wheeler AE, Denninger JW, Mehta DH, Dossett ML. Total Lifestyle Coaching: A Pilot Study Evaluating the Effectiveness of a Mind-Body and Nutrition Telephone Coaching Program for 
Obese Adults at a Community Health Center. Glob Adv Heal Med. 2018;7:216495611878490.

43. Tanaka K, Sasai H, Wakaba K, Murakami S, Ueda M, Yamagata F, Sawada M, Takekoshi K. Professional dietary coaching within a group chat using a smartphone application for weight loss: A randomized controlled trial. J Multidiscip Healthc. 2018;11:339-47.

44. Godino JG, Golaszewski NM, Norman GJ, Rock CL, Griswold WG, Arredondo E, Marshall S, Kolodziejczyk J, Dillon L, Raab F, et al. Text messaging and brief phone calls for weight loss in overweight and obese English-and Spanishspeaking adults: A 1-year, parallel-group, randomized controlled trial. PLoS Med [Internet]. 2019;16:1-17. Available from: http://dx.doi.org/10.1371/journal.pmed.1002917

45. Sakane N, Kotani K, Suganuma A, Takahashi K, Sato J, Suzuki S, Izumi K, Kato M, Noda M, Nirengi S, et al. Prevention of Metabolic Syndrome by TelephoneDelivered Lifestyle Intervention in a Real-World Setting: Sub-Analysis of a Cluster-Randomized Trial. Metab Syndr Relat Disord. 2019;17:355-61.

46. Gill DP, Blunt W, Boa Sorte Silva NC, Stiller-Moldovan C, Zou GY, Petrella RJ. The HealtheSteps ${ }^{\mathrm{TM}}$ lifestyle prescription program to improve physical activity and modifiable risk factors for chronic disease: A pragmatic randomized controlled trial. BMC Public Health. BMC Public Health; 2019;19:1-15.

47. Everett E, Kane B, Yoo A, Dobs A, Mathioudakis N. A Novel Approach for Fully Automated, Personalized Health Coaching for Adults with Prediabetes: Pilot Clinical Trial. J Med Internet Res. 2018;

48. Blackberry ID, Furler JS, Best JD, Chondros P, Vale M, Walker C, Dunning T, Segal L, Dunbar J, Audehm R, et al. Effectiveness of general practice based, 
practice nurse led telephone coaching on glycaemic control of type 2 diabetes: The Patient Engagement and Coaching for Health $(\mathrm{PEACH})$ pragmatic cluster randomised controlled trial. BMJ. 2013;347:1-14.

49. Browning C, Chapman A, Yang H, Liu S, Zhang T, Enticott JC, Thomas SA. Management of type 2 diabetes in China: The Happy Life Club, a pragmatic cluster randomised controlled trial using health coaches. BMJ Open. 2016;6.

50. Wennehorst K, Mildenstein K, Saliger B, Tigges C, Diehl H, Keil T, Englert H. A Comprehensive Lifestyle Intervention to Prevent Type 2 Diabetes and Cardiovascular Diseases: the German CHIP Trial. Prev Sci. 2016;17:386-97.

51. Wayne N, Ritvo P. Smartphone-enabled health coach intervention for people with diabetes from a modest socioeconomic strata community: Single-Arm longitudinal feasibility study. J Med Internet Res. 2014;

52. Wayne N, Perez DF, Kaplan DM, Ritvo P. Health coaching reduces hbalc in type 2 diabetic patients from a lower-socioeconomic status community: A randomized controlled trial. J Med Internet Res. 2015;

53. Shahnazari M, Ceresa C, Foley S, Fong A, Zidaru E, Moody S. NutritionFocused Wellness Coaching Promotes a Reduction in Body Weight in Overweight US Veterans. J Acad Nutr Diet. 2013;

54. Cha E, Kim KH, Umpierrez G, Dawkins CR, Bello MK, Lerner H, Narayan V, Dunbar SB. A feasibility study to develop a diabetes prevention program for young adults with prediabetes using digital platforms and a hand held device. Diabetes Educ. 2014;40:626-37.

55. Coventry P, Bower P, Blakemore A, Baker E, Hann M, Li J, Paisley A, Gibson M. Satisfaction with a digitally-enabled telephone health coaching intervention for people with non-diabetic hyperglycaemia. npj Digit Med [Internet]. Springer 
US; 2019;2:1-9. Available from: http://dx.doi.org/10.1038/s41746-019-0080-6

56. Djuric Z, Segar M, Orizondo C, Mann J, Faison M, Peddireddy N, Paletta M, Locke A. Delivery of health coaching by medical assistants in primary care. J Am Board Fam Med. 2017;30:362-70.

57. Aschbrenner KA, Naslund JA, Barre LK, Mueser KT, Kinney A, Bartels SJ. Peer health coaching for overweight and obese individuals with serious mental illness: intervention development and initial feasibility study. Transl Behav Med. $2015 ; 5: 277-84$.

58. Bartels SJ, Pratt SI, Aschbrenner KA, Barre LK, Naslund JA, Wolfe R, Xie H, McHugo GJ, Jimenez DE, Jue K, et al. Pragmatic replication trial of health promotion coaching for obesity in serious mental illness and maintenance of outcomes. Am J Psychiatry. 2015;

59. Speyer H, Christian Brix Nørgaard H, Birk M, Karlsen M, Storch Jakobsen A, Pedersen K, Hjorthøj C, Pisinger C, Gluud C, Mors O, et al. The CHANGE trial: No superiority of lifestyle coaching plus care coordination plus treatment as usual compared to treatment as usual alone in reducing risk of cardiovascular disease in adults with schizophrenia spectrum disorders and abdominal obesity. World Psychiatry. 2016;15:155-65.

60. Kelly JT, Conley M, Hoffmann T, Craig JC, Tong A, Reidlinger DP, Reeves MM, Howard K, Krishnasamy R, Kurtkoti J, et al. A coaching program to improve dietary intake of patients with ckd entice-ckd. Clin J Am Soc Nephrol. 2020;15:330-40.

61. Looijmans A, Jörg F, Bruggeman R, Schoevers RA, Corpeleijn E. Multimodal lifestyle intervention using a web-based tool to improve cardiometabolic health in patients with serious mental illness: Results of a cluster randomized controlled 
trial (LION). BMC Psychiatry. BMC Psychiatry; 2019;19:1-12.

62. Prochaska JO, Velicer WF. The Transtheoretical Model of Health Behavior Change. Am J Heal Promot [Internet]. 1997;12:38-48. Available from: https://pdfs.semanticscholar.org/d8d1/915aa556ec4ff962efe2a99295dd2e8bda89. pdf

63. Miller WR. Motivational interviewing: Research, practice, and puzzles. Addict Behav. 1996;21:835-42.

64. Rubak S, Sandbæk A, Lauritzen T, Christensen B. Motivational interviewing: A systematic review and meta-analysis. Br J Gen Pract. 2005;55:305-12.

65. Patel ML, Wakayama LN, Bass MB, Breland JY. Motivational interviewing in eHealth and telehealth interventions for weight loss: A systematic review. Preventive Medicine. 2019.

66. Yun YH, Lim C Il, Lee ES, Kim YT, Shin KH, Kim Y, Park KJ, Jeong S, Ryu KW, Han W, et al. Efficacy of health coaching and a web-based program on physical activity, weight, and distress management among cancer survivors: A multi-centered randomised controlled trial. Psychooncology. 2020;1-10.

67. Kim SE, Sweet CMC, Cho E, Tsai J, Cousineau MR. Evaluation of a digital diabetes prevention program adapted for low-income patients, 2016-2018. Prev Chronic Dis. 2019;16:1-12.

68. Choi BG, Dhawan T, Metzger K, Marshall L, Akbar A, Jain T, Young HA, Katz RJ. Image-based mobile system for dietary management in an American cardiology population: Pilot randomized controlled Trial to assess the efficacy of dietary coaching delivered via a Smartphone app versus traditional counseling. J Med Internet Res. 2019;21:1-13.

69. Mao AY, Chen C, Magana C, Caballero Barajas K, Olayiwola JN. A Mobile 
Phone-Based Health Coaching Intervention for Weight Loss and Blood Pressure Reduction in a National Payer Population: A Retrospective Study. JMIR mHealth uHealth. 2017;

70. Sangster J, Furber S, Allman-Farinelli M, Phongsavan P, Redfern J, Haas M, Church J, Mark A, Bauman A. Effectiveness of a Pedometer-Based Telephone Coaching Program on Weight and Physical Activity for People Referred to a Cardiac Rehabilitation Program: A randomized controlled trial. J Cardiopulm Rehabil Prev. 2015;35:124-9.

71. Varney JE, Weiland TJ, Inder WJ, Jelinek GA. Effect of hospital-based telephone coaching on glycaemic control and adherence to management guidelines in type 2 diabetes, a randomised controlled trial. Intern Med J. 2014;44:890-7. 
Table 1. Characteristics of coaching interventions that evaluated the effectiveness of self-reported health coaching for weight loss

\begin{tabular}{|c|c|c|c|c|c|c|c|c|c|c|c|}
\hline Author (data) & $\mathrm{n}$ & Groups & Population & Sex & Type of coach & Behavior target & $\begin{array}{l}\text { Guiding Concepts } \\
\text { Identified }\end{array}$ & $\begin{array}{c}\text { Outcomes } \\
1\end{array}$ & $\begin{array}{l}\text { Duration } \\
\text { (weeks) }\end{array}$ & $\begin{array}{l}\text { Frequency } \\
\text { of contact }\end{array}$ & Time $^{* 2}$ \\
\hline Yun et al.(66) & 394 & $\begin{array}{c}\text { Health } \\
\text { coaching }+ \\
\text { web group x } \\
\text { web-only } \\
\text { group x } \\
\text { control group }\end{array}$ & $\begin{array}{l}\text { Patients cancer } \\
\text { survivors }\end{array}$ & q0 & $\begin{array}{c}\text { Web-based program and } \\
\text { health } \\
\text { Coaching }\end{array}$ & $\begin{array}{l}\text { Physical activity; weight } \\
\text { and positive growth }\end{array}$ & NR & BMI & 24 & Twenty sessions & NR \\
\hline $\begin{array}{l}\text { Kelly et } \\
\text { al.(60) }\end{array}$ & 80 & $\begin{array}{l}\text { Coaching } \mathrm{x} \\
\text { control group }\end{array}$ & $\begin{array}{l}\text { Patients with } \\
\text { chronic kidney } \\
\text { disease }\end{array}$ & q ${ }^{\lambda}$ & $\begin{array}{l}\text { Telephone-based health } \\
\text { coaching }\end{array}$ & Diet & $\begin{array}{l}\text { Behavior change, } \\
\text { motivational } \\
\text { interviewing }\end{array}$ & $\begin{array}{l}\text { Weight, } \\
\text { WC }\end{array}$ & 24 & $\begin{array}{l}\text { Phase one ) Call every } 2 \mathrm{w} \text { and } \\
1 \text { message per w/ Phase two) } 1 \\
\text { message per week }\end{array}$ & NR \\
\hline $\begin{array}{c}\text { Kim et al. } \\
(67)\end{array}$ & 227 & $\begin{array}{l}\text { Coaching } \mathrm{x} \\
\text { aged matched } \\
\text { control group }\end{array}$ & $\begin{array}{l}\text { Patients with } \\
\text { diabetes }\end{array}$ & q⿻一丿 & Virtual health coaching & Diet and physical activity & NR & $\begin{array}{l}\text { BMI, } \\
\text { Weight }\end{array}$ & 52 & Weekly & NR \\
\hline $\begin{array}{l}\text { Looijmans et } \\
\text { al.(61) }\end{array}$ & 244 & $\begin{array}{l}\text { Coaching } \mathrm{x} \\
\text { usual care }\end{array}$ & $\begin{array}{l}\text { Patients with } \\
\text { serious } \\
\text { mental illness }\end{array}$ & q $0^{\lambda}$ & $\begin{array}{l}\text { In person and with a web } \\
\text { tool }\end{array}$ & $\begin{array}{c}\text { Based on the patients' } \\
\text { needs }\end{array}$ & $\begin{array}{c}\text { Motivational } \\
\text { interviewing and the } \\
\text { stage of change model }\end{array}$ & BMI, WC & 48 & Biweekly & $15 \mathrm{~min}$ \\
\hline $\begin{array}{l}\text { Godino et } \\
\text { al.(44) }\end{array}$ & 298 & $\begin{array}{c}\text { Coaching with } \\
\text { call x coaching } \\
\text { text's only } x \\
\text { control group }\end{array}$ & $\begin{array}{l}\text { overweight and } \\
\text { obese adults }\end{array}$ & 우 & $\begin{array}{l}\text { Telephone-based health } \\
\text { coaching }\end{array}$ & $\begin{array}{l}\text { Diet, sedentary behavior, } \\
\text { and physical activity }\end{array}$ & Social cognitive theory & $\begin{array}{l}\text { BMI, } \\
\text { weight }\end{array}$ & 48 & Daily messages & 5 to $10 \mathrm{~min}$ (calls) \\
\hline $\begin{array}{l}\text { Sakane et } \\
\text { al.(45) }\end{array}$ & $\begin{array}{c}1.59 \\
7\end{array}$ & $\begin{array}{l}\text { Coaching } \mathrm{x} \\
\text { control group }\end{array}$ & $\begin{array}{c}\text { Patients with } \\
\text { fasting Plasma } \\
\text { Glucose (120-125 } \\
\text { mg/dL) }\end{array}$ & q $0^{\lambda}$ & $\begin{array}{l}\text { Telephone-based health } \\
\text { coaching }\end{array}$ & $\begin{array}{l}\text { Exercise habits, dietary } \\
\text { fiber intake, and } \\
\text { restriction of alcohol } \\
\text { intake }\end{array}$ & $\begin{array}{l}\text { Motivational } \\
\text { interviewing }\end{array}$ & $\begin{array}{l}\text { BMI, } \\
\text { Weight, }\end{array}$ & 488 & Six phone calls per year & $\begin{array}{l}15 \text { to } 30 \mathrm{~min} \\
\text { (calls) }\end{array}$ \\
\hline Gill. et al.(46) & 118 & $\begin{array}{l}\text { Coaching } \mathrm{x} \\
\text { control group }\end{array}$ & $\begin{array}{l}\text { Patients with } \\
\text { chronic disease }\end{array}$ & qरे & $\begin{array}{l}\text { In person, smartphone app } \\
\text { and with a web tool (site) }\end{array}$ & $\begin{array}{l}\text { Diet, sedentary behavior, } \\
\text { and physical activity }\end{array}$ & $\begin{array}{l}\text { S. M.A.R.T. goal } \\
\text { setting principles }\end{array}$ & $\begin{array}{l}\text { BMI, } \\
\text { Weight, } \\
\text { WC }\end{array}$ & $72 / 24 *$ & $\begin{array}{l}\text { In person (months } 0,2,4, \text { and } \\
6 \text { )/ other months by eHealth } \\
\text { tools and resources }\end{array}$ & $30-40 \mathrm{~min}$ \\
\hline $\begin{array}{l}\text { Coventry et } \\
\text { al. (55) }\end{array}$ & 209 & $\begin{array}{l}\text { Coaching } \mathrm{x} \\
\text { online } \\
\text { coaching }\end{array}$ & $\begin{array}{c}\text { People with } \\
\text { nondiabetic } \\
\text { hyperglycemia }\end{array}$ & 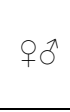 & $\begin{array}{l}\text { Telephone only vs } \\
\text { telephone and online }\end{array}$ & Diet and exercise & $\begin{array}{l}\text { Motivational } \\
\text { interviewing }\end{array}$ & BMI & 36 & Eight calls & $10-40 \mathrm{~min}$ \\
\hline $\begin{array}{l}\text { Choi et al. } \\
\text { (68) }\end{array}$ & 100 & $\begin{array}{l}\text { Coaching } x \\
\text { standard-of- } \\
\quad \text { care }\end{array}$ & $\begin{array}{l}\text { Cardiac patients } \\
\text { overweight or } \\
\text { obese }\end{array}$ & q $0^{\lambda}$ & $\begin{array}{l}\text { Coaching delivered by } \\
\text { smartphone app }\end{array}$ & Diet & NR & $\begin{array}{l}\text { BMI, } \\
\text { Weight }\end{array}$ & 12 & Once & $\begin{array}{l}\text { one session in } \\
\text { person - } 60 \text { min }\end{array}$ \\
\hline
\end{tabular}




\begin{tabular}{|c|c|c|c|c|c|c|c|c|c|c|c|}
\hline $\begin{array}{l}\text { Viglione et al. } \\
\quad(27)\end{array}$ & 45 & $\begin{array}{l}\text { Coaching } x \\
\text { usual care }\end{array}$ & $\begin{array}{l}\text { Veterans } \\
\text { overweight or } \\
\text { obese }\end{array}$ & $\hat{\sigma}$ & $\begin{array}{l}\text { Telephone-based health } \\
\text { coaching }\end{array}$ & Diet and physical activity & 5As framework & Weight & 48 & Twelve calls & $25 \mathrm{~min}$ \\
\hline $\begin{array}{l}\text { Chapman et } \\
\text { al.(37) }\end{array}$ & 711 & $\begin{array}{l}\text { Coaching } \mathrm{x} \\
\text { usual care }\end{array}$ & $\begin{array}{l}\text { Patients with } \\
\text { diabetes }\end{array}$ & qरे & $\begin{array}{l}\text { In person and telephone- } \\
\text { based }\end{array}$ & $\begin{array}{l}\text { Management targets as } \\
\text { specified within the } \\
\text { Chinese diabetes } \\
\text { guidelines }\end{array}$ & $\begin{array}{l}\text { Motivational } \\
\text { interviewing }\end{array}$ & $\begin{array}{l}\text { BMI, } \\
\text { Weight, } \\
\text { WC }\end{array}$ & 72 & $\begin{array}{c}\text { Phase one) Once per week / } \\
\text { Phase two) } 3 \text { per } \mathrm{m} / \text { Phase } \\
\text { three) } 2 \text { per } \mathrm{m} / \text { Phase four) } 1 \\
\text { per } \mathrm{m}\end{array}$ & NR \\
\hline $\begin{array}{l}\text { Johnson et al. } \\
\text { (29) }\end{array}$ & 30 & $\begin{array}{c}\text { Coaching in } \\
\text { person } \mathrm{x} \\
\text { coaching } \\
\text { online } \mathrm{x} \\
\text { control group } \\
\end{array}$ & Obese adults & NR & $\begin{array}{l}\text { In person and online } \\
\text { (video conference) }\end{array}$ & Diet and exercise & NR & $\begin{array}{c}\text { BMI, } \\
\text { Weight }\end{array}$ & 12 & Once & NR \\
\hline Bus et al.(38) & 92 & $\begin{array}{l}\text { Coaching in } \\
\text { person } x \\
\text { coaching } \\
\text { online } \\
\end{array}$ & $\begin{array}{c}\text { Obese or } \\
\text { overweight adults }\end{array}$ & $+\hat{+1}$ & $\begin{array}{l}\text { In person and online } \\
\text { (video conference) }\end{array}$ & Diet and exercise & $\begin{array}{l}\text { Motivational } \\
\text { interviewing }\end{array}$ & $\begin{array}{c}\text { BMI, } \\
\text { Weight }\end{array}$ & 8 & Once & NR \\
\hline $\begin{array}{l}\text { Miller et al. } \\
\qquad(39)\end{array}$ & $\begin{array}{c}152 \\
2\end{array}$ & $\begin{array}{l}\text { Telephone- } \\
\text { based health } \\
\text { coaching } \mathrm{x} \\
\text { standard-of- } \\
\text { care }\end{array}$ & $\begin{array}{l}\text { Individuals with } \\
\text { mixed } \\
\text { dyslipidemia }\end{array}$ & $9 \hat{0}$ & $\begin{array}{l}\text { Telephone-based health } \\
\text { coaching }\end{array}$ & Diet and physical activity & $\begin{array}{l}\text { Motivational } \\
\text { interviewing }\end{array}$ & $\begin{array}{l}\text { BMI, } \\
\text { Weight }\end{array}$ & 24 & Three or more calls & $\begin{array}{l}30 \mathrm{initial} / \\
\min \end{array}$ \\
\hline $\begin{array}{l}\text { Williams et } \\
\text { al. }(40)\end{array}$ & 159 & $\begin{array}{c}\text { Telephone- } \\
\text { based health } \\
\text { coaching } \mathrm{x} \\
\text { control group }\end{array}$ & $\begin{array}{c}\text { Patients with } \\
\text { chronic low back } \\
\text { pain who were } \\
\text { overweight or } \\
\text { obese }\end{array}$ & $q \hat{O}$ & $\begin{array}{l}\text { Telephone-based health } \\
\text { coaching }\end{array}$ & Diet and physical activity & $\begin{array}{l}\text { Self Determination } \\
\text { Theory }\end{array}$ & $\begin{array}{l}\text { BMI, } \\
\text { Weight, } \\
\text { WC }\end{array}$ & 24 & Ten calls & NR \\
\hline $\begin{array}{l}\text { Bollyky et al. } \\
\quad(41)\end{array}$ & 330 & $\begin{array}{c}\text { Intensive } \\
\text { lifestyle } \\
\text { coaching x } \\
\text { lightweight } \\
\text { coaching x no } \\
\text { intervention } \\
\end{array}$ & $\begin{array}{l}\text { Patients with } \\
\text { diabetes } \\
\text { overweight or } \\
\text { obese }\end{array}$ & qर & $\begin{array}{l}\text { Telephone-based health } \\
\text { coaching }\end{array}$ & Diet & $\begin{array}{l}\text { AADE7 Self-Care } \\
\text { Behavior guidelines }\end{array}$ & Weight & 12 & One onboarding call & $\begin{array}{l}\text { ILC - } 60 \text { min and } \\
\text { daily messages, } \\
\text { LWC - } 20 \text { min }\end{array}$ \\
\hline $\begin{array}{l}\text { Chad- } \\
\text { Friedman et } \\
\text { al. (42) }\end{array}$ & 27 & $\begin{array}{c}\text { Only one } \\
\text { group of coach }\end{array}$ & $\begin{array}{c}\text { Obese or } \\
\text { overweight adults }\end{array}$ & की & $\begin{array}{l}\text { Telephone-based health } \\
\text { coaching }\end{array}$ & $\begin{array}{l}\text { Diet, exercise, sleep } \\
\text { quality and relaxation } \\
\text { strategy }\end{array}$ & $\begin{array}{l}\text { Motivational } \\
\text { interviewing }\end{array}$ & $\begin{array}{c}\text { BMI, } \\
\text { Weight }\end{array}$ & 24 & $\begin{array}{l}\text { One in person session }+12 \\
\text { calls }\end{array}$ & $20 \min$ \\
\hline $\begin{array}{l}\text { Tanaka et al. } \\
\quad(43)\end{array}$ & 112 & $\begin{array}{l}\text { Coaching x } \\
\text { standard-of- } \\
\text { care }\end{array}$ & $\begin{array}{c}\text { Obese or } \\
\text { overweight adults }\end{array}$ & $q \hat{0}$ & $\begin{array}{l}\text { Coaching delivered by } \\
\text { smartphone app }\end{array}$ & Diet & Transtheoretical model & $\begin{array}{l}\text { Weight, } \\
\text { WC }\end{array}$ & 8 & Daily & NR \\
\hline
\end{tabular}




\begin{tabular}{|c|c|c|c|c|c|c|c|c|c|c|c|}
\hline $\begin{array}{l}\text { Everett et al. } \\
\quad(47)\end{array}$ & 55 & $\begin{array}{c}\text { Only one } \\
\text { group of coach }\end{array}$ & $\begin{array}{l}\text { Adults with } \\
\text { prediabetes }\end{array}$ & क्र & $\begin{array}{l}\text { Coaching delivered by } \\
\text { smartphone app }\end{array}$ & Diet and physical activity & $\begin{array}{l}\text { Behavioral change } \\
\text { theory }\end{array}$ & $\begin{array}{l}\text { BMI, } \\
\text { Weight, } \\
\text { WC }\end{array}$ & 16 & Daily & $\begin{array}{l}\text { The app provided } \\
\text { just-in-time } \\
\text { adaptive support } \\
\text { in the form of } \\
\text { daily push } \\
\text { notifications. }\end{array}$ \\
\hline $\begin{array}{l}\text { Taveras et al. } \\
\text { (30) }\end{array}$ & 721 & $\begin{array}{l}\text { Coaching x } \\
\text { standard-of- } \\
\quad \text { care }\end{array}$ & Obese children & q0 & $\begin{array}{l}\text { Telephone-based health } \\
\text { coaching and video } \\
\text { conference }\end{array}$ & $\begin{array}{l}\text { Diet, exercise and, sleep } \\
\text { quality }\end{array}$ & $\begin{array}{l}\text { Motivational } \\
\text { interviewing }\end{array}$ & BMI & 48 & $\begin{array}{l}\text { Twice-weekly text messages } \\
\text { and telephone or video } \\
\text { contacts every other month }\end{array}$ & $\begin{array}{l}\text { video contacts - } \\
15-20 \mathrm{~min}\end{array}$ \\
\hline $\begin{array}{l}\text { Mao et al. } \\
\text { (69) }\end{array}$ & 836 & $\begin{array}{l}\text { Coaching x } \\
\text { matched-pair } \\
\text { control }\end{array}$ & $\begin{array}{c}\text { Obese or } \\
\text { overweight adults }\end{array}$ & क्र & $\begin{array}{l}\text { Telephone-based health } \\
\text { coaching }\end{array}$ & $\begin{array}{l}\text { Healthy nutrition, } \\
\text { physical activity, stress } \\
\text { management, and } \\
\text { medication adherence }\end{array}$ & NR & Weight & 16 & Daily & NR \\
\hline $\begin{array}{l}\text { Djuric et al. } \\
\quad(56)\end{array}$ & 82 & $\begin{array}{c}\text { Only one } \\
\text { group of coach }\end{array}$ & $\begin{array}{c}\text { Obese or } \\
\text { overweight adults }\end{array}$ & की & $\begin{array}{l}\text { In person and telephone- } \\
\text { based }\end{array}$ & $\begin{array}{l}\text { Sleep, diet, and/or } \\
\text { physical activity }\end{array}$ & $\begin{array}{c}\text { Motivational } \\
\text { interviewing and } \\
\text { autonomous goal } \\
\text { setting }\end{array}$ & BMI, WC & 12 & Twice & $\begin{array}{c}\text { The initial } \\
\text { coaching session } \\
\text { typically lasted } \\
\text { one hour (average } \\
54 \text { minutes, SD } \\
17 \text { min). Follow- } \\
\text { up coaching } \\
\text { sessions averaged } \\
14 \text { minutes each } \\
\text { (SD } 6 \text { min). }\end{array}$ \\
\hline $\begin{array}{l}\text { Lancha, } \\
\text { Sforzo and } \\
\text { lancha et al. } \\
\quad(26)\end{array}$ & 1 & Case report & One obese male & $\hat{0}$ & In person & $\begin{array}{l}\text { Nutritional coaching was } \\
\text { prompting } \\
\text { motivation for physical } \\
\text { activity practice. }\end{array}$ & $\begin{array}{c}\text { Motivational } \\
\text { interviewing, } \\
\text { decisional balance, } \\
\text { positive psychology, } \\
\text { transtheoretical model. }\end{array}$ & $\begin{array}{l}\text { BMI, } \\
\text { Weight, } \\
\text { WC }\end{array}$ & 12 & Once & $45 \min$ \\
\hline $\begin{array}{l}\text { Browning et } \\
\text { al.(49) }\end{array}$ & 711 & $\begin{array}{l}\text { Coaching } \mathrm{x} \\
\text { usual care }\end{array}$ & $\begin{array}{l}\text { Patients with } \\
\text { diabetes }\end{array}$ & +की & $\begin{array}{l}\text { In person and telephone- } \\
\text { based }\end{array}$ & $\begin{array}{l}\text { Management targets as } \\
\text { specified within the } \\
\text { Chinese diabetes } \\
\text { guidelines }\end{array}$ & $\begin{array}{l}\text { Motivational } \\
\text { interviewing }\end{array}$ & $\begin{array}{l}\text { BMI, } \\
\text { Weight, } \\
\text { WC }\end{array}$ & 24 & $\begin{array}{c}\text { Phase one) Once per week / } \\
\text { Phase two) } 3 \text { per } \mathrm{m} / \text { Phase } \\
\text { three) } 2 \text { per } \mathrm{m} / \text { Phase four) } 1 \\
\text { per } \mathrm{m}\end{array}$ & NR \\
\hline $\begin{array}{l}\text { Speyer et al. } \\
\quad(59)\end{array}$ & 428 & $\begin{array}{c}\text { Coaching } \mathrm{x} \\
\text { care } \\
\text { coordination } \mathrm{x} \\
\text { standard-of- } \\
\text { care } \\
\end{array}$ & $\begin{array}{l}\text { Adults with } \\
\text { severe mental } \\
\text { illness and } \\
\text { overweight }\end{array}$ & की & $\begin{array}{l}\text { In person and telephone- } \\
\text { based }\end{array}$ & $\begin{array}{l}\text { Diet, physical activity } \\
\text { and -where relevant - } \\
\text { smoking cessation. }\end{array}$ & $\begin{array}{l}\text { Transtheoretical model } \\
\text { and motivational } \\
\text { interviewing }\end{array}$ & $\begin{array}{l}\text { BMI, } \\
\text { Weight, } \\
\text { WC }\end{array}$ & 48 & Once & $\begin{array}{l}\text { variable } \\
\text { duration, often } \\
\text { one hour }\end{array}$ \\
\hline
\end{tabular}




\begin{tabular}{|c|c|c|c|c|c|c|c|c|c|c|c|}
\hline $\begin{array}{l}\text { Wennehorst et } \\
\text { al.(50) }\end{array}$ & 83 & $\begin{array}{l}\text { Coaching } \mathrm{x} \\
\text { usual care }\end{array}$ & $\begin{array}{c}\text { People with } \\
\text { prediabetes, type } \\
2 \text { diabetes, or } \\
\text { were at risk of } \\
\text { developing } \\
\text { diabetes and/or } \\
\text { cardiovascular } \\
\text { diseases }\end{array}$ & $\hat{q 0}$ & In person & $\begin{array}{l}\text { Diet, exercise, health } \\
\text { behavior changes, } \\
\text { including social support, } \\
\text { coping strategies, and } \\
\text { stress management }\end{array}$ & $\begin{array}{c}\text { CHIP hand and } \\
\text { workbooks and } \\
\text { multimedia contents. }\end{array}$ & $\begin{array}{c}\text { BMI, } \\
\text { Weight, } \\
\text { WC }\end{array}$ & 8 & Twice & $150 \mathrm{~min}$ \\
\hline $\begin{array}{l}\text { Wayne et al. } \\
\quad(52)\end{array}$ & 131 & $\begin{array}{c}\text { Coaching } \\
\text { delivered by } \\
\text { app x coaching } \\
\text { in person }\end{array}$ & $\begin{array}{l}\text { Patients with type } \\
2 \text { diabetes. }\end{array}$ & qô & $\begin{array}{l}\text { Coaching delivered by } \\
\text { ssmartphone app }\end{array}$ & Diet and exercise & $\begin{array}{l}\text { Behavior change } \\
\text { techniques }\end{array}$ & $\begin{array}{c}\text { BMI, } \\
\text { Weight, } \\
\text { WC }\end{array}$ & 24 & through the app & $\begin{array}{l}\text { App delivered - } \\
\text { not specified }\end{array}$ \\
\hline $\begin{array}{l}\text { Aschbrenner } \\
\text { et al. (57) }\end{array}$ & 10 & $\begin{array}{c}\text { Only one } \\
\text { group ff coach }\end{array}$ & $\begin{array}{l}\text { Overweight and } \\
\text { obese individuals } \\
\text { with serious } \\
\text { mental illness }\end{array}$ & $q 0^{\lambda}$ & In person & Diet and exercise & $\begin{array}{l}\text { Motivational } \\
\text { interviewing, behavior } \\
\text { change techniques }\end{array}$ & Weight & 24 & NR & $60 \mathrm{~min}$ \\
\hline $\begin{array}{l}\text { Bartels et al. } \\
\quad(58)\end{array}$ & 210 & $\begin{array}{l}\text { Coaching } \mathrm{x} \\
\text { fitness club } \\
\text { membership }\end{array}$ & $\begin{array}{l}\text { Overweight and } \\
\text { obese individuals } \\
\text { with serious } \\
\text { mental illness }\end{array}$ & $q \hat{0}$ & In person & Diet and physical activity & $\begin{array}{l}\text { Behavior change } \\
\text { techniques and } \\
\text { motivational } \\
\text { interviewing }\end{array}$ & $\begin{array}{c}\text { BMI, } \\
\text { Weight, } \\
\text { WC }\end{array}$ & 48 & Once & $45-60 \mathrm{~min}$ \\
\hline $\begin{array}{l}\text { Sangster et al. } \\
\quad(70)\end{array}$ & 313 & $\begin{array}{c}\text { Coaching } \\
\text { health weight } \\
\text { x coaching } \\
\text { physical } \\
\text { activity }\end{array}$ & Cardiac patients & 우 & $\begin{array}{l}\text { Telephone-based health } \\
\text { coaching }\end{array}$ & $\begin{array}{l}\text { Health weigh x physical } \\
\text { activity }\end{array}$ & NR & $\begin{array}{c}\text { BMI, } \\
\text { Weight }\end{array}$ & 8 and 6 & $\begin{array}{l}\text { Four calls (CHW) e two calls } \\
\text { (CPA) }\end{array}$ & $13-27 \mathrm{~min}$ \\
\hline $\begin{array}{c}\text { Cha et al. } \\
(54)\end{array}$ & 14 & $\begin{array}{c}\text { Only one } \\
\text { group of coach }\end{array}$ & $\begin{array}{c}\text { Young adults with } \\
\text { prediabetes }\end{array}$ & qर्र & $\begin{array}{l}\text { Coaching delivered by } \\
\text { smartphone app }\end{array}$ & Diet and physical activity & $\begin{array}{l}\text { Social cognitive } \\
\text { theory. }\end{array}$ & $\begin{array}{c}\text { BMI, } \\
\text { Weight }\end{array}$ & 12 & Once & NR \\
\hline $\begin{array}{l}\text { Varney et } \\
\text { al.(71) }\end{array}$ & 94 & $\begin{array}{l}\text { Coaching } \mathrm{x} \\
\text { standard-of- } \\
\text { care }\end{array}$ & $\begin{array}{l}\text { Adults with type } 2 \\
\text { diabetes }\end{array}$ & $q \hat{O}$ & $\begin{array}{l}\text { Telephone-based health } \\
\text { coaching }\end{array}$ & Diet and exercise & NR & $\begin{array}{l}\text { BMI, } \\
\text { Weight, } \\
\text { WC }\end{array}$ & 24 & Six (4-9) coaching sessions & $20-45 \mathrm{~min}$ \\
\hline $\begin{array}{l}\text { Wayne et al. } \\
\quad(51)\end{array}$ & 21 & $\begin{array}{c}\text { Only one } \\
\text { group of coach }\end{array}$ & $\begin{array}{l}\text { Adults with type } 2 \\
\text { diabetes }\end{array}$ & +人र & $\begin{array}{l}\text { Coaching delivered by } \\
\text { smartphone app }\end{array}$ & $\begin{array}{l}\text { Diet, physical activity, } \\
\text { and overall health goals }\end{array}$ & $\begin{array}{l}\text { Behavior change } \\
\text { techniques }\end{array}$ & $\begin{array}{l}\text { BMI, } \\
\text { Weight, } \\
\text { WC }\end{array}$ & 24 & through the app & $\begin{array}{l}\text { App delivered - } \\
\text { not specified }\end{array}$ \\
\hline $\begin{array}{l}\text { Shahnazari et } \\
\text { al.(53) }\end{array}$ & 84 & $\begin{array}{l}\text { Coaching } \mathrm{x} \\
\text { control group }\end{array}$ & $\begin{array}{c}\text { Veterans } \\
\text { overweight or } \\
\text { obese }\end{array}$ & 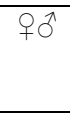 & $\begin{array}{l}\text { Telephone-based health } \\
\text { coaching }\end{array}$ & Diet & Transtheoretical model & Weight & 24 & $\begin{array}{l}\text { Phase one) one per week/ } \\
\text { Phase two one per month }\end{array}$ & $\begin{array}{c}\text { 60-min session; } \\
\text { final session } 15 \\
\text { min }\end{array}$ \\
\hline $\begin{array}{l}\text { Blackberry et } \\
\text { al. (48) }\end{array}$ & 468 & $\begin{array}{l}\text { Coaching } \mathrm{x} \\
\text { control group }\end{array}$ & $\begin{array}{l}\text { Patients with } \\
\text { diabetes }\end{array}$ & $q \hat{O}$ & $\begin{array}{l}\text { Telephone-based health } \\
\text { coaching and in person }\end{array}$ & $\begin{array}{l}\text { Dealing with lifestyle } \\
\text { issues, medication } \\
\text { adherence and dosing, } \\
\text { self monitoring of their }\end{array}$ & Patient empowerment & $\begin{array}{l}\text { Weight, } \\
\text { WC }\end{array}$ & 72 & $\begin{array}{l}\text { Once each } 6 \text { w (for } 6 \text { months) } \\
+4 \text { sessions (in an interval of } \\
4 \text { months) }\end{array}$ & NR \\
\hline
\end{tabular}


disease

\begin{tabular}{|c|c|c|c|c|c|c|c|c|c|c|c|}
\hline $\begin{array}{l}\text { Hawkes et al. } \\
\qquad(32)\end{array}$ & 22 & $\begin{array}{c}\text { Only one } \\
\text { group of coach }\end{array}$ & $\begin{array}{l}\text { Patients with } \\
\text { colorectal cancer }\end{array}$ & 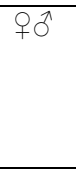 & $\begin{array}{l}\text { Telephone-based health } \\
\text { coaching }\end{array}$ & $\begin{array}{l}\text { Diet, physical activity, } \\
\text { weight management, } \\
\text { alcohol and smoking }\end{array}$ & $\begin{array}{c}\text { Behavioral models of } \\
\text { health and illness and } \\
\text { behaviour change, } \\
\text { Acceptance } \\
\text { Commitment }\end{array}$ & BMI, WC & 6 & Once & $60 \mathrm{~min}$ \\
\hline $\begin{array}{l}\text { Ball et al. } \\
\text { (31) }\end{array}$ & 46 & $\begin{array}{c}\text { Health } \\
\text { initiatives } \\
\text { program x } \\
\text { youth lifestyle } \\
\text { program } \\
\text { x control } \\
\text { group } \\
\end{array}$ & Obese adolescents & q⿳亠丷厂 & In person & Diet and physical activity & $\begin{array}{c}\text { Motivational } \\
\text { interviewing and } \\
\text { cognitive behavioral } \\
\text { therapy (one group) }\end{array}$ & $\begin{array}{l}\text { BMI, } \\
\text { Weight, } \\
\text { WC }\end{array}$ & $16-20$ & Sixteen sessions & $45-60 \mathrm{~min}$ \\
\hline $\begin{array}{l}\text { Rimmer et al. } \\
\text { (28) }\end{array}$ & 92 & $\begin{array}{l}\text { Lower support } \\
\text { x higher } \\
\text { support } \mathrm{x} \\
\text { control group }\end{array}$ & $\begin{array}{l}\text { Women with } \\
\text { severe obesity and } \\
\text { mobility disability }\end{array}$ & 운 & $\begin{array}{l}\text { Telephone-based health } \\
\text { coaching }\end{array}$ & Exercise & NR & $\begin{array}{l}\text { BMI, } \\
\text { Weight }\end{array}$ & 48 & Once & $5-35 \mathrm{~min}$ \\
\hline
\end{tabular}

Legend: BMI - body mass index; CHIP - German Version of Comprehensive Health Improvement Project ; CHW - Coaching health weight; CPA- coaching physical activity;

$\mathrm{m}$-months; min - minutes; NR- not reported; WC - Waist Circumference; $q$ - female; $\widehat{\partial}$ - male;

${ }^{1}$ Outcomes analysed by the review's authors*; ${ }^{2}$ Time - duration of the coach session; 
Table 1. Assessment of methodological quality of the studies that evaluated the effectiveness of self-reported health coaching for weight loss

\begin{tabular}{|c|c|c|c|c|c|c|c|c|c|}
\hline \multirow[b]{2}{*}{ Outcome } & \multicolumn{5}{|c|}{ Downgrading Factors } & \multicolumn{3}{|c|}{ Upgrading Factors } & \multirow[b]{2}{*}{ GRADE } \\
\hline & Risk of Bias & Directness & Consistency & Precision & $\begin{array}{c}\text { Publication } \\
\text { Bias }\end{array}$ & $\begin{array}{l}\text { Large } \\
\text { Effects }\end{array}$ & $\begin{array}{c}\text { Dose- } \\
\text { Response }\end{array}$ & $\begin{array}{c}\text { Residual } \\
\text { Confounders }\end{array}$ & \\
\hline Primary meta-analysis ${ }^{1}$ & $\oplus \oplus \oplus 0$ & $\oplus 000$ & $\oplus 000$ & $\oplus 000$ & $\oplus 000$ & $\oplus 000$ & $\oplus 000$ & $\oplus 000$ & $\oplus 000$ \\
\hline Secondary meta-analysis $^{2}$ & $\oplus \oplus \oplus 0$ & $\oplus 000$ & $\oplus 000$ & $\oplus 000$ & $\oplus 000$ & $\oplus 000$ & $\oplus 000$ & $\oplus 000$ & $\oplus 000$ \\
\hline Sensitivity analysis based on high-quality RCTs ${ }^{3}$ & $\oplus \oplus \oplus \oplus$ & $\oplus \oplus \oplus \oplus$ & $\oplus \oplus \oplus \oplus$ & $\oplus \oplus \oplus \oplus$ & $\oplus \oplus \oplus \oplus$ & $\oplus \oplus \oplus \oplus$ & $\oplus \oplus \oplus \oplus$ & $\oplus \oplus \oplus \oplus$ & $\oplus \oplus \oplus \oplus$ \\
\hline
\end{tabular}

Legend: $\oplus \oplus \oplus \oplus$ High quality; $\oplus \oplus \oplus 0$ Moderate quality; $\oplus \oplus 00$ Low quality and $\oplus 000$ Very low

${ }^{1}$ Primary meta-analysis was with 16 controlled studies comprising 47 outcomes indicated a trivial effect favouring the inclusion of coaching compared to usual care; ${ }^{2}$ secondary meta-analysis was conducted using the pre-post data from coaching interventions only (both controlled and before-after designs). ${ }^{3}$ Analysis based on those studied determined to be of high quality. 


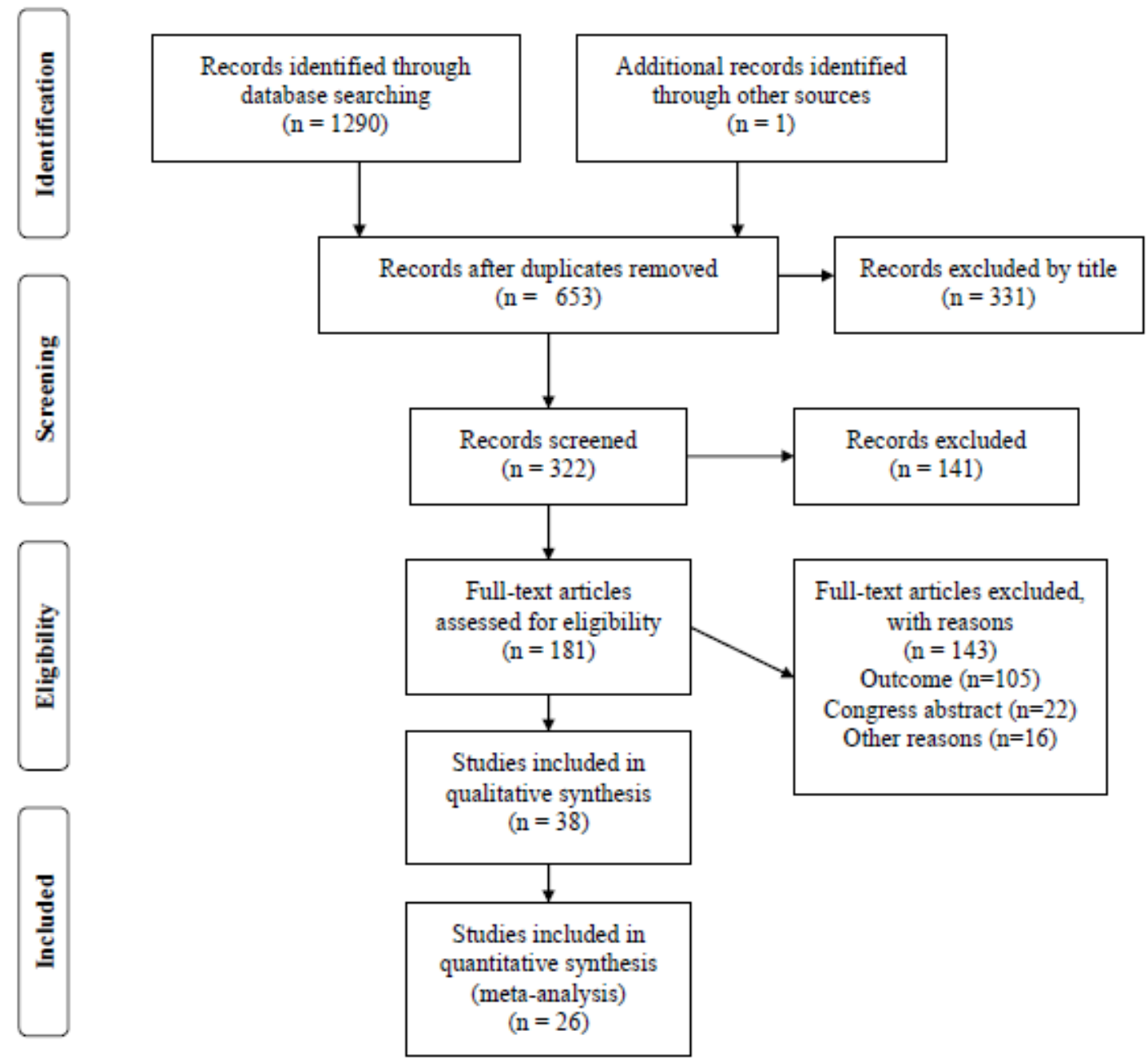

Figure 1. Flow diagram illustrating literature search and selection process of studies assessing self-reported health coaching for weight loss 


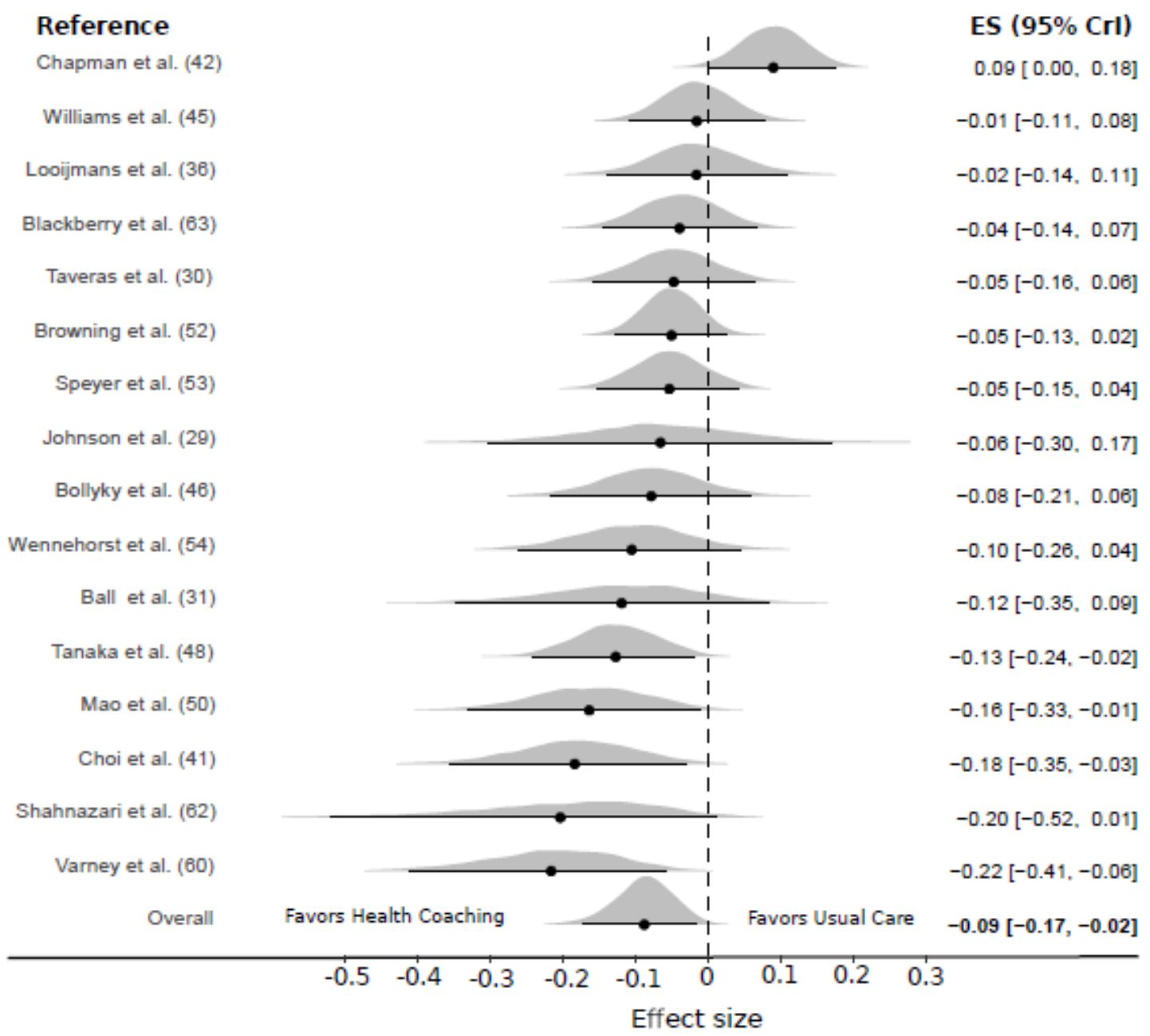

Figure 2. Bayesian forest plots of modelled study effect sizes assessing self-reported health coaching on weight loss outcomes.

Legend: Comparison of health coaching $(n=2501)$ with usual care $(n=1729)$ 


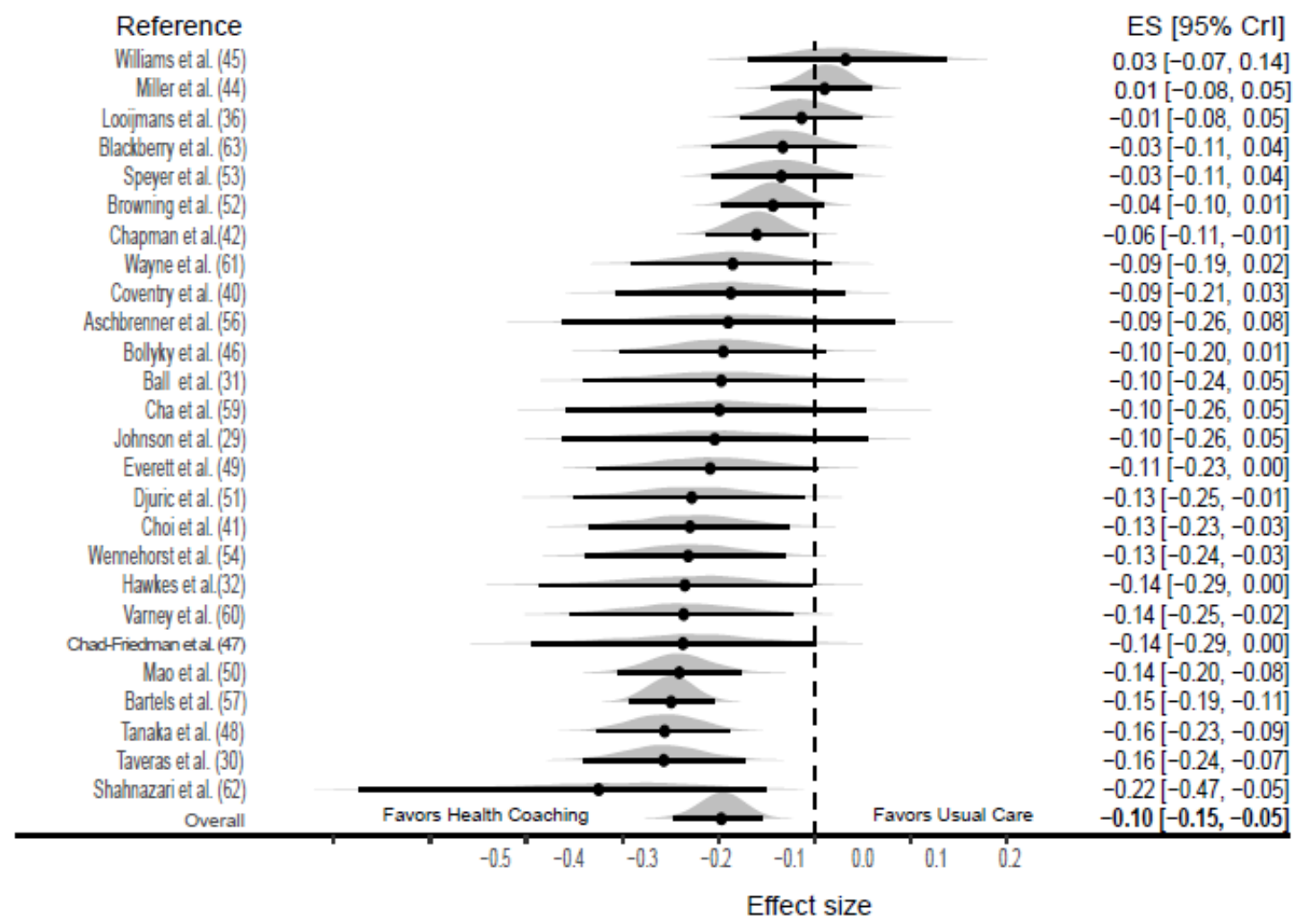

Figure 3. Pooled effect sizes assessing self-reported health coaching on weight loss outcomes.

Legend: Comparison of pre-post data from those allocated to health coaching $(n=$ $3601)$. 